

open Access Full Text Article
Available online on 28.11.2021 at http://jddtonline.info

\section{Journal of Drug Delivery and Therapeutics}

Open Access to Pharmaceutical and Medical Research

Copyright (C) 2021 The Author(s): This is an open-access article distributed under the terms of the CC BY-NC 4.0 which permits unrestricted use, distribution, and reproduction in any medium for non-commercial use provided the original author and source are credited



Research Article

\title{
Evaluation of Antiepileptic Activity of Flowers of Cocos nucifera L. Against Experimentally Induced Convulsions in Rats
}

\author{
Archana B*1(D), Ravi Naik Mudavath 2(D), Vinay Enumula 3(D), N Ravali 4 (D), Paka Sravan Kumar 5 (D) \\ 1. Assistant Professor, Department of Pharmacology, St. Mary's group of institution, Deshmukhi (Village), Pochampally (Mandal), Yadadri \\ Bhuvanagiri (Dist), Telangana-508284, India.
}

2. Department of Pharmacology, JSS College of Pharmacy, JSS Academy of Higher Education \& Research, Ooty-643001, The Nilgiris,Tamil Nadu, India.

3. Department of Pharmacology, National Research Institute of Unani medicine for skin disorders (Formerly central research institute of Unani medicine), Opposite ESI Hospital, AG Colony Road, Erragadda, Hyderabad-500038, Telangana State, India

4. Assistant Professor, Department of Pharmacology, Vaageswari College of Pharmacy, Beside LMD Police Station, Ramakrishna Colony, Thimmapur, Karimnagar-505527, Telangana State, India.

5. Assistant Professor, Department of Pharmacology, St. Mary's group of institution, Deshmukhi (Village), Pochampally (Mandal), Yadadri Bhuvanagiri (Dist), Telangana-508284, India.

\section{Article Info:}

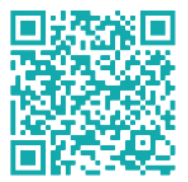

\section{Article History:}

Received 18 September 2021 Reviewed 09 November 2021 Accepted 21 November 2021 Published 28 November 2021

\section{Cite this article as:}

B A, Mudavath RN, Enumula V, Ravali N, Sravan Kumar P, Evaluation of Antiepileptic Activity of Flowers of Cocos nucifera L. Against Experimentally Induced Convulsions in Rats, Journal of Drug Delivery and Therapeutics. 2021; 11(6):159-166

DOI: http://dx.doi.org/10.22270/jddt.v11i6.5097

*Address for Correspondence:

Archana B, Assistant Professor, Department of Pharmacology, St. Mary's group of institution, Deshmukhi (Village), Pochampally (Mandal), Yadadri Bhuvanagiri (Dist), Telangana-508284, India.

ORCID ID: http://orcid.org/0000-0002-1144-3849

\section{Abstract}

The report used to be planned to analyze the antiepileptic activity of Cocos nucifera flowers against special experimentally induced convulsions in rats. In the present study, antiepileptic activity was assessed by following experimental models. Anti-convulsant in vivo models: Maximal electroshocks (MES) induced models in rats, Pentylenetetrazole (PTZ) induced in rats. Pretreatment of animals with Cocos nucifera flowers extract has reduced by half the general continuance of tonic hind leg extension, the most commonly used endpoint in assessing clonic convulsions. MES provokes repetitive neuronal firing indicates epileptic neurons. MES is the widely accepted model to demonstrate the antiepileptic property of a drug. This property is antagonistic of the plant extract could flow from to blockade of voltage-gated sodium channel or due to effect on NMDA receptors. The Cocos nucifera flowers extract was also demonstrated potential anticonvulsant activity in PTZ induced convulsions and this may be due to its agonistic activity on the GABA receptor. This is further supported by an elevated level of GABA by the plant extract in the PTZ model. Methanolic extract of Cocos nucifera flowers has shown significant anticonvulsant activity against MES and Pentlylenetetrazole induced convulsion models. This observed activity could also be the referable presence of flavonoids and other phytochemical constituents found in the powerful extract.

Keywords: Cocos nucifera, antiepileptic activity, Maximal electroshock, Pentlylenetetrazole, Flavonoids,

\section{INTRODUCTION}

Epilepsy is defined as abnormal electrical activity in the brain. Epilepsy is a common neurological disease characterized by paroxysmal cerebral dysrhythmia, visualizing for the reason that aphoristic trailers going from sum or disturbance of consciousness, without or with distinctive body movement, sensorial or psychiatric consequence. Epilepsy has a central origin in the brain; manifestations depend on the site of focus, regions into which the discharges spread, and postictal depression of this region. Epilepsy has been known at the time of antiquity. The coconut Cocos nucifera Linn has been defined as the "tree about life operating room tree going from heaven in addition to nature's life" supreme gift to human beings. To each one component of the overall cocoa, the palm can be utilized to supply perfume invaluable for the overall boat club. Cocos nucifera $\mathrm{L}$. is a leading type tree belonging to the family Arecaceae (palm). The common name of Cocos nucifera is the coconut plant. From the earliest time, the different parts of Cocos nucifera have been used for the treatment of various disease states in the Indian system of medicine. The purpose of the study is to evaluate the epileptic activity of flowers of Cocos nucifera against experimentally induced convulsions in rats. 


\section{MATERIALS AND METHODS}

Drugs and Chemicals Phenytoin was purchased from Medico Remedies Ltd., Maharastra, India, diazepam was procured from Prem Pharmaceuticals Ltd., Indore, Madhya Pradesh, India and pentylenetetrazole (PTZ) and GABA was purchased from Yerrow chem Mumbai, India. All other solvents and chemicals used were of analytical grade purchased from Hi-Media Laboratories Pvt., Ltd., Bengaluru, India.

\section{METHODOLOGY}

\section{Preparation of extract}

Fresh flowers of Cocos nucifera have always been specter dried at room temperature and coarse powdered and extracted with methanol by Soxhlet's Apparatus. Then the extract was concentrated by using a rotary flash evaporator to obtain semisolid crude extract. The \% yield of the Cocos nucifera flowers methanolic extract was found to be $22.79 \%$. The methanolic extract was preserved and kept in an airtight bottle in a refrigerator below $10^{\circ} \mathrm{C}$. The suitable concentration of stock solutions of the extract was prepared using distilled water and it is used following studies ${ }^{1}$.

1. Detection of Preliminary phytochemical investigation.

2. Detection of Acute toxicity study in mice.

3. Evaluation of the crude extracts of Cocos nucifera flowers for the anticonvulsant property against

a. Maximal electroshock (MES) triggered convulsion models in rat

b. Pentylenetetrazole (PTZ) triggered convulsion.

\section{Preliminary phytochemical screening}

The preliminary phytochemical screening conveys out for methanol extract of Cocos nucifera flowers for the presence of phytoconstituents. The tests for common phytochemicals were carried out by the following methods as described in the journal of preliminary phytochemical screening of Cocos nucifera flowers ${ }^{2}$.

\section{Determination of acute toxicity $\left(L_{50}\right)$}

Acute toxicity of different extracts of Cocos nucifera flowers extract was executed on female albino mice (20-30 g). The animals have fasted overnight before the experiment. Fixeddose (OECD Guideline No. 423) method was personalized for toxicity studies. $1 / 5^{\text {th }} \mathrm{LD}_{50}$ cut-off value of the extract was selected given that screening dose for the anticonvulsant activity of extract of Cocos nucifera flowers ${ }^{3}$.

\section{Experimental animals}

The Wistar rats 150-200 g of either sex were used in the experimentation. Animal Ethics committee approval no. 1688/PO/E/2020/CPCSEA, Sanztme Ltd Healthcare Business, Hyderabad. After randomization into various teams of animals were acclimatized for 10 days under standard husbandry conditions, and room temperature at 27 $\pm 3^{\circ}$, relative humidity $65 \pm 10 \%, 12 \mathrm{hr}$. light or dark cycle. All the animals were fed with a rodent food diet (Pavan Agro's Industries, Sangli, India) and water was allowed ad libitium under severe hygienic conditions ${ }^{4}$.

3. Evaluation of the crude extract of Cocos nucifera flowers for anticonvulsant

Property against

A) Maximal electroshock (MES) induced models in rats
B) Pentylenetetrazole (PTZ) induced.

\section{A. Maximal Electroshock (MES) seizure}

Electrical stimulation was applied using ear electrodes. The electrodes have been moistened with saline before application. All animals were stimulated with $150 \mathrm{~mA}$ for 0.2 seconds, with consisting voltage stimulator of $250 \mathrm{~V}$. The animals are divided into five groups. Each group consists of 6 animals both sexual activities 5 .

Group I: Normal Saline (0.5ml P.O for 15 days) + MES on 15th day

Group II: Phenytoin sodium (25mg/kg p.o for 15 days) + MES on 15th day

Group III: Cocos nucifera flower extract (CNFE) $(125 \mathrm{mg} / \mathrm{kg}$ p.o for 15 days) + MES on 15th day

Group IV: CNFE (250mg/kg p.o for 15 days) + MES on 15 th day

Group V: CNFE (500mg/kg p.o for 15 days) + MES on 15 th day

On the 15th day, the test samples were given that 1 hour before generalization of convulsions. Stifling of tonic hind limb extension die for a measure of efficacy in this test.

\section{B. Pentylenetetrazole (PTZ) triggered convulsion}

PTZ $60 \mathrm{mg} / \mathrm{kg}$ I.P was administered to rats. The parameter noted was the time scale(duration) of convulsions. The animals were divided into five groups 6 . Each group consisted of 6 males and 6 females $(\mathrm{n}=12)$.

Group I: Normal Saline (0.5ml p.o for 15 days) + PTZ on 15th day

Group II: Diazepam (2mg/kg p.o for 15 days) + PTZ on 15 th day

Group III: CNFE (125mg/kg p.o for 15 days) + PTZ on 15 th day

Group IV: CNFE (250mg/kg p.o for 15 days) + PTZ on 15 th day

Group V: CNFE (500mg/kg p.o for 15 days) + PTZ on 15 th day

On the 15th day, the test samples were given 1 hour before induction of convulsions. Termination of the leg pain gives up for as valuate of affectivity in this test 7 .

\section{GABA Estimation}

For the estimation of GABA levels in PTZ induced animals, animals were divided into six groups, and each group consisted of six rats. The rats were sacrificed $45 \mathrm{~min}$ after Cocos nucifera extract or vehicle and $30 \mathrm{~min}$ after diazepam. All Group of animal was sacrificed after the onset of convulsions occurs or $65 \mathrm{sec}$ after PTZ injection. The rat brain was immediately isolated and transferred into a homogenization tube and the tube containing $5 \mathrm{ml} 0.01 \mathrm{M}$ hydrochloric acid and homogenized the content. Afterward, the homogenized brain was transferred into $8 \mathrm{ml}$ of the ice cold absolute alcohol containing bottle and at $0^{\circ} \mathrm{C}$ kept it for $1 \mathrm{hr}$. And then the content was centrifuged at 16,000 rpm for $10 \mathrm{~min}$, and then the upper part or supernatant was collected in a Petri dish. Then the precipitate was washed three times with $5 \mathrm{ml}$ of $75 \%$ alcohol and washes were mixed with supernatant. And the Petri dish contents were disappeared at $70{ }^{\circ} \mathrm{C}$ for dryness on a water bath under stream air ${ }^{8}$. And to the dry mass $2 \mathrm{ml}$ chloroform and $1 \mathrm{ml}$ water were added and for 10 min centrifuged at 2,000 rpm. 
And upper containing phase is GABA, in that $2.0 \mathrm{ml}$ was separated and $0.1 \mathrm{ml}$ of it was applied on whatman paper No.41 as spot. The mobile phase was prepared and it consists of $12 \mathrm{ml}$ acetic acid, $60 \mathrm{ml}$ water, and $50 \mathrm{ml} \mathrm{n}$ butanol. The chamber was kept for half an hour for saturation with the mobile phase. The chromatography paper was developed with ascending technique. The paper was dried in a hot air oven and then spread with $0.5 \%$ ninhydrin solution in $95 \%$ ethanol on chromatography paper. And then the paper was dried at $90 \mathrm{c}$ for $1 \mathrm{hr}$. Blue color spot developed on paper and the blue color spot was cut and heated with $2 \mathrm{ml}$ ninhydrin solution for 5 min on a water bath. Then $5.0 \mathrm{ml}$ of water was added to the solution and kept for $1 \mathrm{~h}$. Then supernatant $2.0 \mathrm{ml}$ was decanted and absorbance was measured at $570 \mathrm{~nm}{ }^{9}$.

\section{Statistical Significance}

The data obtained from the above findings were subjected to statistical analysis using one-way ANOVA followed by Tukey's Kramer Multiple Comparison Test to assess the statistical significance of the results. The $\mathrm{p}<0.01$ implies significance $1^{0}$.

\section{RESULTS}

\section{Practical yield}

The practical yield of Cocos nucifera flowers extract from Soxhlet extraction was evaporated to dryness by using a rotary flash evaporator. The yield of Cocos nucifera flowers finds to be $22.79 \% \mathrm{w} / \mathrm{w}$.

\section{Preliminary phytochemical screening}

Results of the preliminary phytochemical investigation on methanolic extract of Cocos nucifera flowers [Table 1].

\section{Determination of acute toxicity $\mathrm{LD}_{50}$}

The methanolic extract of Cocos nucifera flowers turned into calculated given that acute toxicity at a dose of $2000 \mathrm{mg} / \mathrm{kg}$ p.o. in albino mice. The extracts find devoid containing mortality of the animals. Hence $2500 \mathrm{mg} / \mathrm{kg}$ were regarded as $\mathrm{LD}_{50}$ cut-off value.

So the screening doses selected for the evaluation of anticonvulsant activity as per OECD guidelines No. 423 and fixed dose method are mentioned under

1. $125 \mathrm{mg} / \mathrm{kg}$ methanolic extract $\left(1 / 20^{\text {th }}\right.$ of $\left.2500 \mathrm{mg} / \mathrm{kg}\right)$.

2. $250 \mathrm{mg} / \mathrm{kg}$ methanolic extract ( $1 / 10^{\text {th }}$ of $\left.2500 \mathrm{mg} / \mathrm{kg}\right)$.

3. $500 \mathrm{mg} / \mathrm{kg}$ methanolic extract $\left(1 / 5^{\text {th }}\right.$ of $\left.2500 \mathrm{mg} / \mathrm{kg}\right)$.

\section{Anticonvulsant study}

Effect of Cocos nucifera flowers extract on MES induced seizures

The effect of Cocos nucifera flowers extract on MES triggered involuntary movements in rats will be summarized successfully the general in Table 2 . The CNFE at $250 \mathrm{mg} / \mathrm{kg}$ and $500 \mathrm{mg} / \mathrm{kg}$ p.o. have significantly delayed the attack in addition to reducing the duration containing hind limb extension seizure (HLES) compared to control. There were been no significant alterations in the latency consisting of convulsions compared to regulating at the dose of $125 \mathrm{mg} / \mathrm{kg}$. However, the extract as well exhibited $22 \%$, $43 \%$, and $46 \%$ protection in hind limb extension at the doses of $125 \mathrm{mg} / \mathrm{kg}, 250 \mathrm{mg} / \mathrm{kg}, 500 \mathrm{mg} / \mathrm{kg}$ respectively, though it all become $72 \%$ in hydantoin, standard drug-treated rats [Figure 1, 2, 3 \& 4].

Effect of Cocos nucifera flowers extract on Pentylenetetrazole (PTZ) induced seizures

The effect of Cocos nucifera flowers extract on PTZ triggered seizures in rats determined in Table 3. The plant extract CNFE at $500 \mathrm{mg} / \mathrm{kg}$ p.o indicates important onset containing PTZ caused seizures in addition to less significant clonic convulsions. At $125 \mathrm{mg} / \mathrm{kg}$ and $250 \mathrm{mg} / \mathrm{kg}$ p.o. that it also indicates onset containing involuntary movements and duration of clonic convulsions in PTZ taste-maker other than outcome find planned mathematically non-significant. CNFE at $500 \mathrm{mg} / \mathrm{kg}$ p.o exhibited $66 \%$ consisting of inoculating towards the duration of clonus convulsion, though it used to $74 \%$ in diazepam dosed grouping [Figure 5, 6, 7 \& 8].

\section{GABA Estimation}

The effect of Cocos nucifera flowers extract on GABA level in PTZ triggered seizures in rats indicated in Table 4. In this present research work, we found that GABA level was decreased in controlled rats were as, the title plant extract at $500 \mathrm{mg} / \mathrm{kg}$ p.o has significantly increased GABA level. The extract at $125 \mathrm{mg} / \mathrm{kg}, 250 \mathrm{mg} / \mathrm{kg}$ as well multiplied GABA level but mathematically it finds to be non-significant. The standard drug has also greatly magnified the GABA level [Figure $9 \& 10$ ].

Table 1: Results of the preliminary phytochemicals investigation in the methanolic extract of Cocos nucifera flowers

\begin{tabular}{|l|c|}
\hline Phytochemical constituents & Inference \\
\hline Flavonoids & Present \\
\hline Alkaloids & Present \\
\hline Phenol & Present \\
\hline Phytosterols & Absent \\
\hline Saponins & Absent \\
\hline Tannins & Absent \\
\hline Carbohydrates & Present \\
\hline Aminoacids & Present \\
\hline Anthraquinones & Absent \\
\hline
\end{tabular}


Table 2: Effect of $C$. Nucifera flowers extract on MES model in rats

\begin{tabular}{|l|l|l|l|l|l|l|l|}
\hline Group & Treatment & Dose & $\begin{array}{l}\text { Flexion in } \\
\text { (sec) }\end{array}$ & $\begin{array}{l}\text { Extension in } \\
\text { (sec) }\end{array}$ & $\begin{array}{l}\text { Clonus in } \\
\text { (sec) }\end{array}$ & $\begin{array}{l}\text { Stupor in } \\
\text { (sec) }\end{array}$ & $\begin{array}{l}\text { Protection } \\
\text { against the } \\
\text { extension } \\
\text { (\%) }\end{array}$ \\
\hline 1 & Vehicle & $0.5 \mathrm{ml}$ & $12.00 \pm 1.183$ & $16.50 \pm 0.56$ & $16.50 \pm 1.23$ & $12.00 \pm 10.87$ & -- \\
\hline 2 & $\begin{array}{l}\text { Phenytoin } \\
\text { sodium }\end{array}$ & $25 \mathrm{mg} / \mathrm{kg}$ & $2.50 \pm 0.428^{* * *}$ & $4.60 \pm 0.33^{* * *}$ & $4.80 \pm 0.30^{* * *}$ & $32.83 \pm 1.55^{* * *}$ & 72 \\
\hline 3 & CNFE & $125 \mathrm{mg} / \mathrm{kg}$ & $10.33 \pm 0.61^{\mathrm{ns}}$ & $12.80 \pm 1.01^{* *}$ & $13.00 \pm 0.61^{*}$ & $90.00 \pm 7.14^{*}$ & 22 \\
\hline 4 & CNFE & $250 \mathrm{mg} / \mathrm{kg}$ & $8.66 \pm 0.21^{*}$ & $9.30 \pm 0.42^{* * *}$ & $12.00 \pm 0.68^{* *}$ & $77.00 \pm 7.34^{* *}$ & 43 \\
\hline 5 & CNFE & $500 \mathrm{mg} / \mathrm{kg}$ & $4.33 \pm 0.42^{* * *}$ & $8.83 \pm 0.60^{* * *}$ & $7.60 \pm 0.49^{* * *}$ & $40.50 \pm 3.04^{* * *}$ & 46 \\
\hline
\end{tabular}

Consequences have been verbalised given that Mean \pm SEM, $n=6$. Significance at ${ }^{*} \mathrm{p}<0.05,{ }^{* *} \mathrm{p}<0.01,{ }^{* * *} \mathrm{p}<0.001$, and non-significant $\mathrm{v} / \mathrm{s}$ control.



Treatment

Figure 1: Effect of C. Nucifera flowers extract on MES induced flexion in rats



Treatment

Figure 2: Effect of $C$. Nucifera flowers extract on MES induced extension in rats
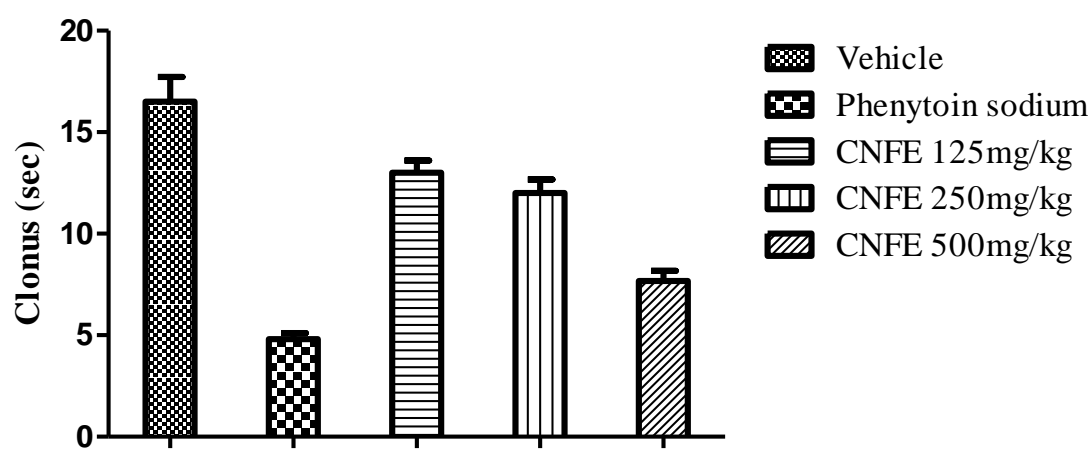

Treatment

Figure 3: Effect of $C$. Nucifera flowers extract on MES induced clonus in rats 


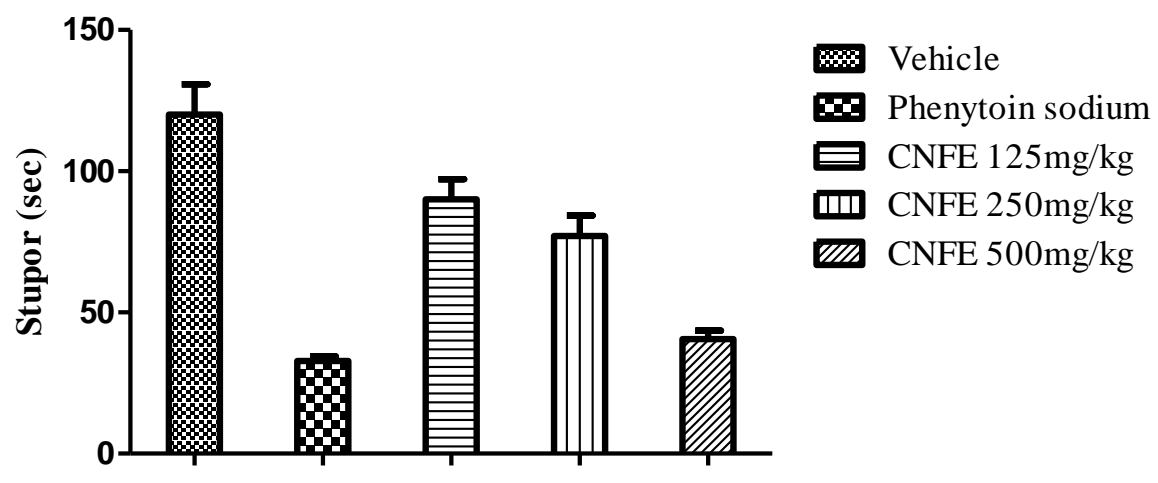

Treatment

Figure 4: Effect of $C$. Nucifera flowers extract on MES induced stupor in rats

Table: 3 Effect of $\boldsymbol{C}$. Nucifera flowers extract on PTZ induced model in rats

\begin{tabular}{|l|l|l|l|l|l|l|l|}
\hline Group & Treatment & Dose & $\begin{array}{l}\text { Onset of jerks } \\
\text { (sec) }\end{array}$ & $\begin{array}{l}\text { Onset of Clonus } \\
\text { (sec) }\end{array}$ & $\begin{array}{l}\text { Duration of } \\
\text { Clonus (sec) }\end{array}$ & $\begin{array}{l}\text { Onset of } \\
\text { Extension (sec) }\end{array}$ & $\begin{array}{l}\text { Protection } \\
\text { against } \\
\text { clonus (\%) }\end{array}$ \\
\hline $\mathbf{1}$ & Vehicle & $0.5 \mathrm{ml}$ & $65.00 \pm 6.19$ & $322.66 \pm 10.08$ & $22.16 \pm 4.75$ & $136.66 \pm 20.44$ & -- \\
\hline $\mathbf{2}$ & Diazepam & $2 \mathrm{mg} / \mathrm{kg}$ & $122.60 \pm 6.79^{* * *}$ & $468.33 \pm 16.4^{* * *}$ & $5.66 \pm 0.55^{* *}$ & $43.00 \pm 1.82^{* * *}$ & 74 \\
\hline $\mathbf{3}$ & CNFE & $125 \mathrm{mg} / \mathrm{kg}$ & $65.16 \pm 6.68^{\mathrm{ns}}$ & $333.50 \pm 17.42^{\mathrm{ns}}$ & $19.33 \pm 3.85^{\mathrm{ns}}$ & $121.66 \pm 20.60 \mathrm{~ns}$ & 12 \\
\hline $\mathbf{4}$ & CNFE & $250 \mathrm{mg} / \mathrm{kg}$ & $69.83 \pm 6.24^{\mathrm{ns}}$ & $361.83 \pm 21.27^{\mathrm{ns}}$ & $13.16 \pm 2.14^{\mathrm{ns}}$ & $107.50 \pm 11.50^{\mathrm{ns}}$ & 38 \\
\hline $\mathbf{5}$ & CNFE & $500 \mathrm{mg} / \mathrm{kg}$ & $101.66 \pm 5.20^{* *}$ & $434.33 \pm 9.98^{* * *}$ & $7.33 \pm 0.76^{*}$ & $45.00 \pm 1.50^{* * *}$ & 66 \\
\hline
\end{tabular}

Consequences have been verbalised given that Mean \pm SEM, $n=6$. Significance at ${ }^{*} \mathrm{p}<0.05,{ }^{* *} \mathrm{p}<0.01,{ }^{* * *} \mathrm{p}<0.001$, and non-significant $\mathrm{v} / \mathrm{s}$ control.

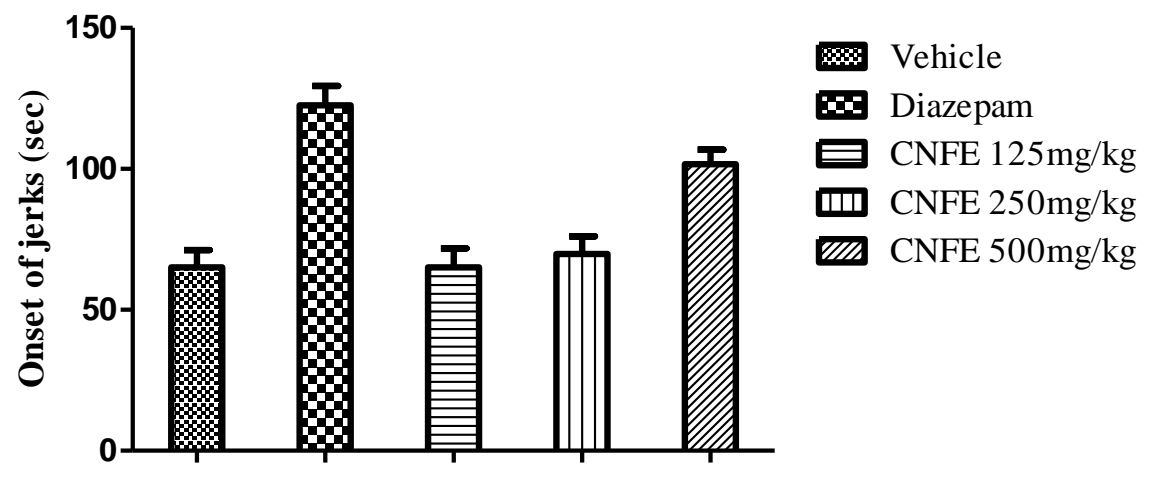

Treatment

Figure 5: Effect of $C$. Nucifera flowers extract on PTZ induced onset of jerks in rats



Treatment

Figure 6: Effect of $C$. Nucifera flowers extract on PTZ induced onset of clonus in rats 


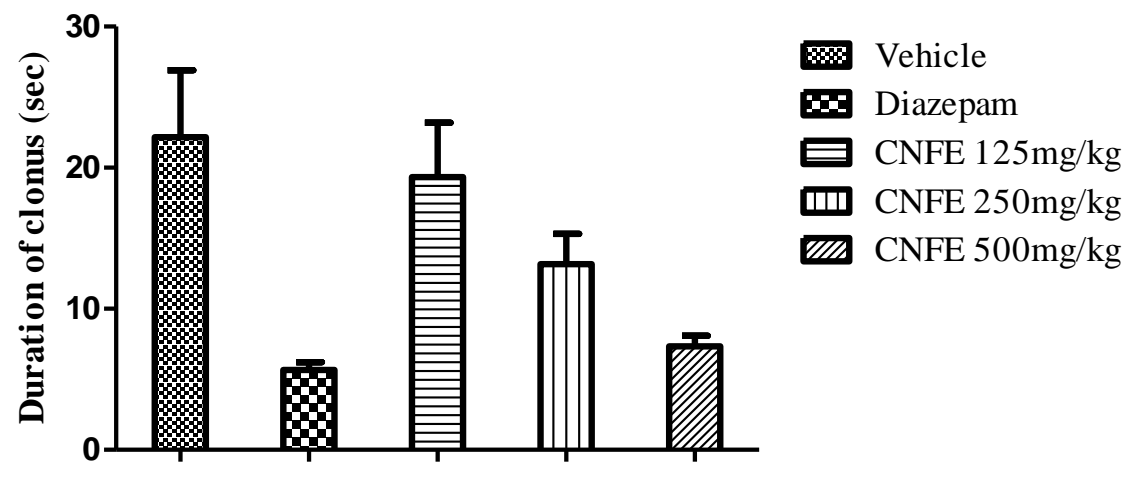

Treatment

Figure 7: Effect of $C$. Nucifera flowers extract on PTZ induced duration of clonus in rats

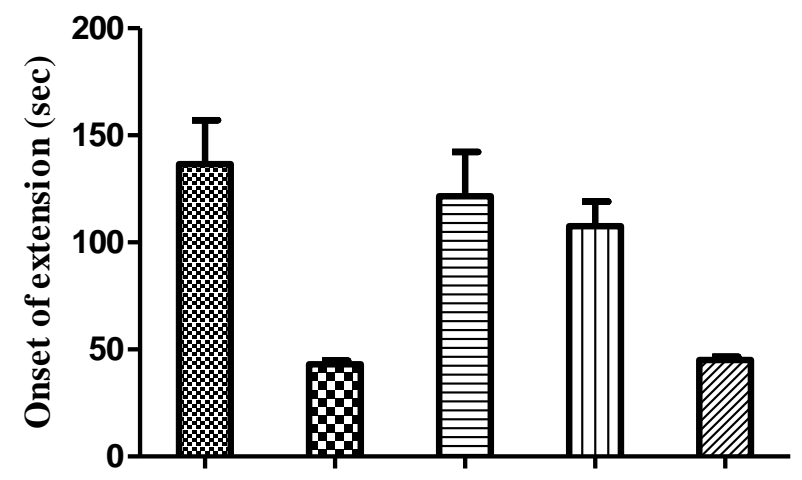

ॠehicle

00 Diazepam

○ CNFE $125 \mathrm{mg} / \mathrm{kg}$

西 CNFE $250 \mathrm{mg} / \mathrm{kg}$

III CNFE $500 \mathrm{mg} / \mathrm{kg}$

\section{Treatment}

Figure 8: Effect of $C$. Nucifera flowers extract on PTZ induced onset of Extension in rats

Table 4: Effect of $\boldsymbol{C}$. Nucifera flowers extract on GABA level in PTZ induced model in rats

\begin{tabular}{|l|l|l|l|}
\hline Group & Treatment & Dose & GABA Level \\
\hline 1 & Normal control & --- & $269.85 \pm 3.46$ \\
\hline 2 & Control & Vehicle & $189.47 \pm 2.88$ \\
\hline 3 & Diazepam & $2 \mathrm{mg} / \mathrm{kg}$ & $258.62 \pm 4.03^{* * *}$ \\
\hline 4 & CNFE & $125 \mathrm{mg} / \mathrm{kg}$ & $192.37 \pm 3.62^{\mathrm{ns}}$ \\
\hline 5 & CNFE & $250 \mathrm{mg} / \mathrm{kg}$ & $204.35 \pm 4.06^{* * *}$ \\
\hline 6 & CNFE & $500 \mathrm{mg} / \mathrm{kg}$ & $246.89 \pm 3.61^{* * *}$ \\
\hline
\end{tabular}

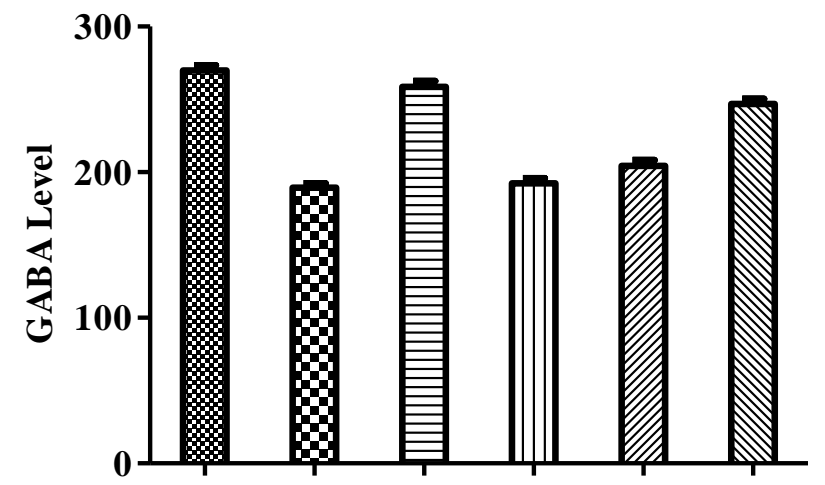

\% Normal control

Ex Control

曰Diazepam $2 \mathrm{mg} / \mathrm{kg}$

(I) CNFE $125 \mathrm{mg} / \mathrm{kg}$

CNFE $250 \mathrm{mg} / \mathrm{kg}$

CNFE $500 \mathrm{mg} / \mathrm{kg}$

\section{Treatment}

Figure 9: Effect of $C$. Nucifera flowers extract on GABA level in PTZ induced model in rats 




A.Flexion

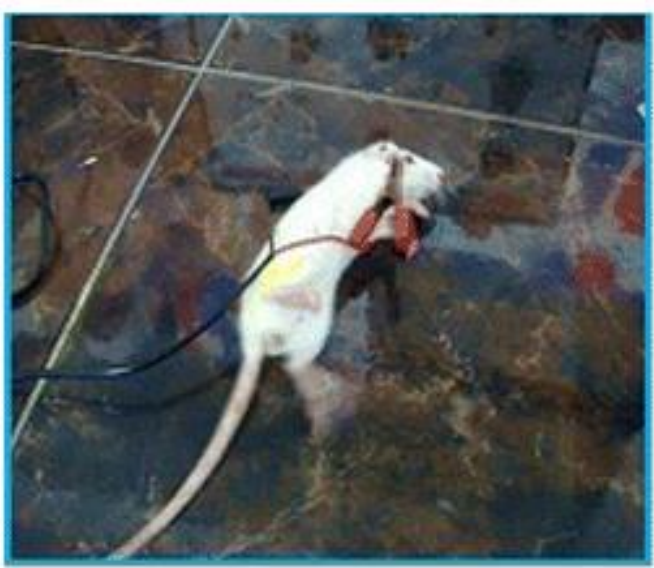

C.Clonus

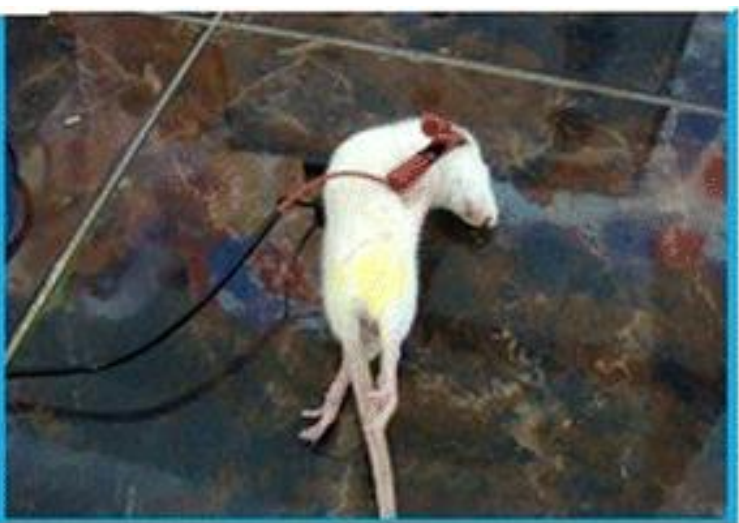

B.Extension

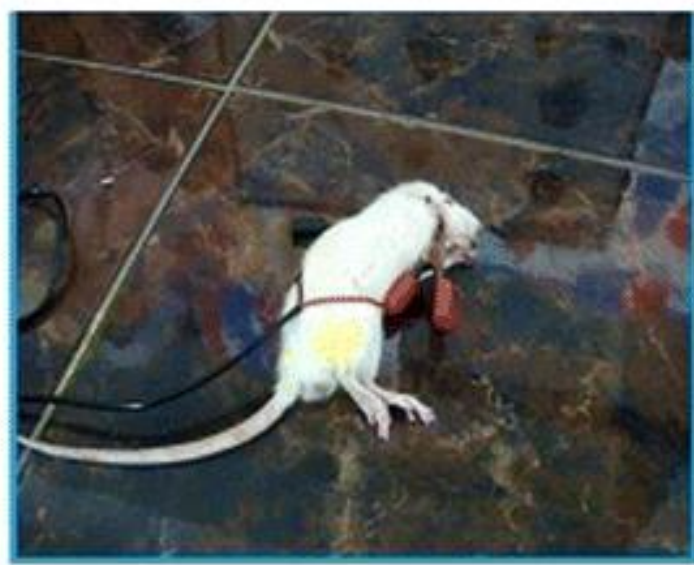

D.Stupor

Figure 10: Different stages involved in experimentally induced convulsions

\section{DISCUSSION}

Epilepsy is defined as paroxysmal cerebral dysrhythmia Epilepsy (Encephalopathy) is a common neurological disease that has effects on a variety of people inside the world. It can be a disorder of the brain characterized by undeterminable and irregular (periodic) happening consisting of a transitory of behaviour due to the disordered, synchronous, and rhythmic firing of populations of brain neurons.

Currently, many synthetic anticonvulsant drugs are available for the management, control, and treatment of epileptic patients. However, most of the drugs are high cost and inaccessible and also produce adverse effects. Hence, there is a need for the potential anticonvulsant drug which is low cost and safe.

Since ancient times medicinal plants are useful drugs known to humans. Literature survey indicates that, many plants are possessing anticonvulsant activity and which can serve as an alternative to allopathic drugs. The present analysis was once well-intentioned to investigate the antiepileptic activity of methanolic extract of Cocos nucifera flowers.

In the present study, it is evident that the Cocos nucifera flower ameliorates the convulsions induced by MES and PTZ animals. The commonly used epileptic models to study antiepileptic drugs are MES and PTZ induced convulsions. The general biography was written document famous that GABAergic neurotransmission can be prevalent with the overall stimulus consisting of epilepsy.
Pretreatment of animals with Cocos nucifera flowers extract has significantly reduced the duration of tonic hind limb extension, the most commonly used endpoint in assessing clonic convulsions.

Electroshock, Electrical stimulation at the brain, provokes repetitive neuronal firing indicates epileptic neurons. MES is the widely accepted model to demonstrate the antiepileptic property of a drug. Our study exhibits that Cocos nucifera flowers have shown potential anticonvulsant effect in this model by effectively reducing hind limb extension.

MES caused involuntary movements to affect oxidative damage, in addition, to having been abolished by the drugs that block voltage-gated sodium channels like phenytoin sodium or drugs that block NMDA receptors like felbamate.

In the PTZ model convulsions are abolished by drugs that possess $\mathrm{GABA}_{\mathrm{A}}$ agonists like diazepam or block T-type $\mathrm{Ca}^{+2}$ current in the thalamus like valproate.

In MES and PTZ models, convulsions are produced by inhibiting the activity of $\mathrm{GABA}_{\mathrm{A}}$ receptors. GABA is the major inhibiting neurotransmitter implicated in epilepsy. Inhibition of neurotransmitters of GABA will cause convulsions whereas enhancement attenuates it.

Diazepam, a standard antiepileptic drug, displays glamour consequence by way of battering GABAergic neurotransmission within the unconscious mind.

The abolishing of MES-induced seizures by the Cocos nucifera flowers extract suggests anticonvulsant activity in generalized tonic-clonic seizures. The present belongings the 
plant life find time for may well be imputable stymie epithetical voltage-gated sodium channel or referable its antagonistic upshot in the NMDA receptors.

The Cocos nucifera flowers extract was also demonstrated potential anticonvulsant activity in PTZ induced convulsions and this may be due to its agonistic activity on the GABAA receptor. This is further supported by an elevated level of GABA by the plant extract in the PTZ model.

\section{CONCLUSION}

Methanolic make time for containing Cocos nucifera flowers gave an important anticonvulsant activity against MES and PTZ caused epileptic seizure fashions. That cited utilization can be because of ubiquity containing flavonoids along with other phytochemical constituents found in the sensational slot in.

\section{ACKNOWLEDGEMENT}

I would like to thanks Principal sir (Dr Kamal Hassan) St. Mary's Group of Institutions, Deshmukhi (Village), Pochampally (Mandal), Yadadri Bhuvanagiri(Dist), Telangana-508284, India.

\section{Conflict of Interest}

The authors attest that they have no conflict of interest in this study.

\section{Funding Support}

The authors declare that there is no Financial sup-port for the current study.

\section{BIBLIOGRAPHY}

1. Silva RR, Oliveira e Silva D, Fontes HR, Alviano CS, Fernandes PD, Alviano DS. Anti-inflammatory, antioxidant, and antimicrobial activities of Cocos nucifera var. typica. BMC Complementary and alternative medicine, 2013; 16;13:107. doi: https://doi.org/10.1186/1472-6882-13-107.

2. Alviano DS, Rodrigues KF, Leitão SG, Rodrigues ML, Matheus ME, Fernandes PD, Antoniolli AR, Alviano CS. Antinociceptive and free radical scavenging activities of Cocos nucifera L. (Palmae) husk fiber aqueous extract. Journal of Ethnopharmacology,

$$
\text { 2004; } \quad 92(2-3): 269-73 .
$$

doi: https://doi.org/10.1016/j.jep.2004.03.013.

3. Fisher RS, van Emde Boas W, Blume W, Elger C, Genton P, Lee P, Engel J Jr. Epileptic seizures and epilepsy: definitions proposed by the International League against Epilepsy (ILAE) and the International Bureau for Epilepsy (IBE). Epilepsia. 2005; 46(4):470-2. doi: https://doi.org/10.1111/j.00139580.2005.66104.x.

4. Saranya S, Pradeepa S. Subramanian S. Biochemical Evaluation of antidiabetic activity of Cocos nucifera flowers in STZ induced diabetic rats. International Journal of Pharmaceutical Sciences Review and Research, 2014; 26(1):67-75.

5. Zhu HL, Wan JB, Wang YT, Li BC, Xiang C, He J, Li P. Medicinal compounds with antiepileptic/anticonvulsant activities. Epilepsia. 2014; 55(1):3-16. doi: https://doi.org/10.1111/epi.12463.

6. Rinaldi S, Silva DO, Bello F. Characterization of the antinociceptive and anti-inflammatory activities from Cocos nucifera L. (Palmae). Journal of Ethnopharmacology. 2009 Apr; 122(3):541-546. https://doi.org/10.1016/j.jep.2009.01.024

7. Koschek PR, Alviano DS, Alviano CS, Gattass CR. The husk fiber of Cocos nucifera L. (Palmae) is a source of anti-neoplastic activity. Brazilian Journal of Medical and Biological Research, 2007; 40(10):1339-1343. doi: https://doi.org/10.1590/s0100$879 \times 2006005000153$

8. Snead OC, Banerjee PK, Burnham M, Hampson D. Modulation of absence seizures by the $\operatorname{GABA}(\mathrm{A})$ receptor: A critical rolefor metabotropic glutamate receptor 4 (mGluR4), Journal of $\begin{array}{ll}\text { Neuroscience, } & 2000 ; 20(16): 6218-6224 ; \text { DOI: }\end{array}$ https://doi.org/10.1523/JNEUROSCI.20-16-06218.2000

9. Karim N, Irshad S, Khan I, Mohammad A, Anis I, Shah MR, Khan I, Chebib M. GABA(A) receptor modulation and neuropharmacological activities of viscosine isolated from Dodonaea viscosa (Linn). Pharmacology Biochemistry and Behavior, 2015; 136:64-72. https://doi.org/10.1016/j.pbb.2015.07.006

10. Esquenazi D, Wigg MD, Miranda MM, Rodrigues HM, Tostes JB, Rozental S, da Silva AJ, Alviano CS. Antimicrobial and antiviral activities of polyphenolics from Cocos nucifera Linn. (Palmae) husk fiber extract. Research Microbiology, 2002; 153(10):64752. https://doi.org/10.1016/s0923-2508(02)01377-3 